\title{
INTERNAL CAROTID AND VERTEBRAL ARTERY DISSECTION: MORPHOLOGY, PATHOPHYSIOLOGY AND PROVOKING FACTORS
}

Kalashnikova LA $\otimes$, Gulevskaya TS, Sakharova AV, Chaykovskaya RP, Gubanova MV, Danilova MS, Dobrynina LA, Shabalina AA

Research Center of Neurology, Moscow, Russia

The causes of internal carotid artery (ICA) and vertebral artery (VA) dissection, as well as its provoking factors, remain understudied. The aim of this paper was to explore morphological changes in the ICANA walls, factors provoking dissection, clinical signs and biomarkers of connective tissue (CT) damage. A total of 271 patients were examined, of whom 54\% were women. The mean age of the participants was $37.0 \pm 10$ years. Clinical signs and biomarkers of CT damage (matrix metalloproteinase 9, tissue inhibitor of metalloproteinase 1, hydroxyproline, sulphated glycosaminoglycans) were analyzed in 82 patients and 40 healthy volunteers. Histologic examination of dissected and seemingly intact arteries conducted in 5 cases revealed signs of arterial wall dysplasia similar to those characteristics of fibromuscular dysplasia: thinning and splitting of the internal elastic membrane, areas of fibrosis, irregular orientation of myocytes, and their necrosis in the tunica media. Clinical signs and biomarkers of CT dysplasia (CTD) were more pronounced in patients with arterial dissection than in the controls. The major provoking factors were head turns and physical activity $(42 \%)$, minor head injury (10\%), and acute respiratory infection in the month preceding arterial dissection (14\%). We conclude that arterial wall dysplasia is a predisposing factor for ICANA dissection, both spontaneous and provoked. The analysis of CTD biomarkers and clinical signs suggests connective tissue pathology in patients with ICANA dissection.

Keywords: internal carotid artery dissection, vertebral artery dissection, morphological changes in the arterial wall, clinical signs of connective tissue dysplasia, biomarkers of connective tissue damage, factors provoking dissection

Funding: this study was part of the state assignment for Research Center of Neurology.

Author contribution: Kalashnikova LA, Gubanova MV — literature analysis, data acquisition, processing of the obtained data, manuscript preparation; Gulveskaya TS, Sakharova AV, Chaykovskaya RP, Shabalina AA — data acquisition, analysis and interpretation; Danilova MS — recruitment of participants; Dobrynina LA — processing of the obtained data, manuscript preparation.

Compliance with ethical standards: the study was approved by the Ethics Committee of Research Center of Neurology (Protocol 12/14 dated December 10, 2014). All study participants consented to participate in the study and to have the results published.

$\triangle$ Correspondence should be addressed: Ludmila A. Kalashnikova

Volokolamskoe shosse, 80, Moscow, 125367; kalashnikovancn@yandex.ru

Received: 03.09.2019 Accepted: 19.09.2019 Published online: 03.10.2019

DOI: 10.24075/brsmu.2019.064

\section{ДИССЕКЦИЯ ВНУТРЕННЕЙ СОННОЙ И ПОЗВОНОЧНОЙ АРТЕРИЙ: МОРФОЛОГИЯ, ПАТОФИЗИОЛОГИЯ, ПРОВОЦИРУЮЩИЕ ФАКТОРЫ}

Л. А. Калашникова 凶, Т. С. Гулевская, А. В. Сахарова, Р. П. Чайковская, М. В. Губанова, М. С. Данилова, А. А. Шабалина, Л. А. Добрынина Научный центр неврологии, Москва, Россия

Причина и провоцирующие факторы диссекции внутренней сонной и позвоночной (ВСА/ПА) артерий остаются малоизученными. Целью работы было изучить морфологические изменения стенок ВСА/ПА при диссекции, провоцирующие факторы диссекции, клинические признаки и биомаркеры повреждения соединительной ткани (СТ). Обследован 271 больной (средний возраст — 37,0 \pm 10 лет, женщины - 54\%) с диссекцией ВСА/ПА. Провоцирующие факторы диссекции проанализированы у всех больных. Клинические признаки и биомаркеры повреждения СТ (матриксная металлопротеиназа 9, тканевой ингибитор металлопротеиназы, гидроксипролин, сульфатированные гликозаминогликаны) исследованы у 82 больных и 40 здоровых добровольцев. Гистологическое исследование расслоенных и не расслоенных артерий, проведенное в 5 случаях, обнаружило признаки дисплазии артериальной стенки, сходные с таковыми при фибромышечной дисплазии: истончение, расщепление внутренней эластической мембраны, участки фиброза, неправильной ориентировки и некроза миоцитов в медии. Клинические признаки и биомаркеры дисплазии соединительной ткани (ДСТ) были более выражены при диссекции, чем в контроле. Основными провоцирующими факторами диссекции были повороты головы/сизическая нагрузка (42\%), травма головы, как правило, легкая (10\%), острая респираторная инфекция, перенесенная в течение предшествующего месяца (14\%). Заключение: дисплазия артериальной стенки служит причиной диссекции ВСА/ПА, которая развивается спонтанно или под действием провоцирующих факторов. Исследование биомаркеров и клинических признаков ДСТ указывает на наличие распространенного дефекта СТ у больных с диссекцией ВСА/ПА.

Ключевые слова: диссекция внутренней сонной и позвоночной артерий, морфологические изменения артериальной стенки, клинические признаки дисплазии соединительной ткани, биомаркеры повреждения соединительной ткани, провоцирующие факторы диссекции

Финансирование: работа выполнена в рамках государственного задания ФГБНУ НЦН.

Информация о вкладе авторов: Л. А. Калашникова, М. В. Губанова - анализ литературы, сбор и обработка материала, обработка полученных данных, написание текста статьи; Т. С. Гулевская, А. В. Сахарова, Р. П. Чайковская, А. А. Шабалина - сбор, анализ и интерпретация данных; М. С. Данилова - подбор участников исследования; Л. А. Добрынина - обработка полученных данных, редактирование текста статьи.

Соблюдение этических стандартов: исследование одобрено этическим комитетом ФГБНУ НЦН (протокол № $12 / 14$ от 10 декабря 2014 г.). Все участники исследования подписали добровольное информированное согласие на участие в исследовании и публикацию результатов.

$\bowtie$ Для корреспонденции: Людмила Андреевна Калашникова Волоколамское шоссе, д. 80, г. Москва, 125367; kalashnikovancn@yandex.ru

Статья получена: 03.09.2019 Статья принята к печати: 19.09.2019 Опубликована онлайн: 03.10.2019 DOI: 10.24075 /vrgmu.2019.064

Cervical artery dissection (CeAD) (internal carotid artery - ICA, vertebral artery - VA) occurs when blood enters the arterial wall through an intimal tear and spreads between its layers. This leads to the formation of an intramural hematoma (IMH), less often — to a double lumen or a dissecting aneurysm [1]. The narrowing or occlusion of the arterial lumen by $\mathrm{IMH}$ is the main cause of cerebral ischemia. Another cause of cerebral ischemia is arterio-arterial embolism by blood clots formed at 
the site of the intimal tear. In the absence of hemodynamically significant ICANA stenosis, neck pain and headache can be the only clinical manifestation of CeAD dissection [1, 2].

Until the late 20th century, ICANA dissection was thought to be extremely rare because it was mainly verified on autopsy in cases of fatal stroke. The latter rarely occurs in CeAD, which led to a misconception about the rarity of CeAD. After neuroimaging techniques, such as magnetic resonance angiography (MRA), computed tomography angiography (CTA) and MRI of neck arteries, were introduced into routine clinical practice, it became clear that ICANA dissection was the main cause of ischemic stroke in young adults and that it could be manifested as isolated neck pain and headache [1, 3-7].

In Russia, research of brain-supplying arteries dissection was pioneered by the Research Center of Neurology in the late 1990s, almost simultaneously with the studies conducted abroad. Despite the advancements in the study of clinical and neuroimaging features of arterial dissection, its cause remains poorly understood. Researchers often point to arterial wall weakness in brain-supplying arteries. But because autopsy studies are rare, the nature of arterial wall weakness remains unclear, although some authors report connective tissue disorders in the affected individuals [8, 9]. So far, no mutations have been detected in the collagen gene that could explain the weakness of the arterial wall in CeAD patients [10,11].

The aim of this study was to analyze the following aspects of CeAD: 1) morphological changes in the ICANA wall; 2) clinical signs of connective tissue weakness and biomarkers of connective tissue damage; 3) the main provoking factors for CeAD.

\section{METHODS}

Between 2000 and 2018, we examined 271 patents with CeAD (mean age $-37.0 \pm 10$ years, $54 \%$ women). The inclusion criteria were as follows: the presence of $\mathrm{IMH}$ and/ or characteristic angiographic CeAD signs on neuroimaging. Patients with traumatic CeAD and patients with a typical clinical picture of CeAD not verified by neuroimaging were excluded from the study. Before developing CeAD, all patients considered themselves practically healthy. Clinical manifestations of CeAD included ischemic stroke (63\%), a transient ischemic attack (9\%), isolated neck pain /headache (27\%), or isolated caudal nerve palsy (1\%). Localization of CeAD was as follows: ICA - 139 patients (51\%), VA - 116 patients (43\%), ICA + VA - 16 patients (6\%). Fifty-nine patients (22\%) had multiple dissections involving both VA, both ICA or their combination. Four patients with ICA dissection developed a massive cerebral infarction and died. Their brain-supplying arteries, both dissected and non-dissected, were subjected to a histopathologic examination (Laboratory of Pathological Anatomy, Research Center of Neurology). An ICA fragment was obtained from one patient during reconstructive ICA surgery complicated by its dissection and stroke and subjected to a histopathologic examination. Staining of histological preparations was performed using hematoxylin and eosin, fuchselin (Weigert's method), von Kossa's method for calcium salts detection, and van Gieson's method.

A total of 48 clinical signs of connective tissue dysplasia (CTD) selected from the diagnostic criteria for inherited connective tissue diseases were analyzed in 82 CeAD patients. Every sign was classified as present (1 point) or absent (0 points). In addition, the presence of past history headaches was assessed in all patients. The control group included 40 healthy volunteers (mean age $38.5 \pm 6.6$ years; $62.5 \%$ of them were women.). The serological biomarkers of CTD, including matrix metalloproteinase 9 (MMP-9), tissue inhibitor of metalloproteinase 1 (TIMP-1), hydroxyproline, sulphated glycosaminoglycans, as well as fibroblast growth factor 21 (FGF-21), were measured once using ELISA. Orosomucoid levels were determined in 82 patients using an automated Konelab 30IPrime chemistry analyzer (Thermo Fisher Scientific Oy; Finland). The control subgroup included 25 healthy volunteers (mean age $-36.9 \pm 6.6$ years; $60.1 \%$ of them were women). Provoking factors, the frequency of CeAD recurrence and its seasonal variability were analyzed in all patients.

The IBM SPSS 23.0 (IBM; USA) statistics software package was used for statistical analysis. In this study, quantitative variables are presented as a mean and a standard deviation from the mean; qualitative and ordered categorical variables are presented as frequency and percentage. The normality of qualitative data distribution was tested with the Shapiro-Wilk test. Differences between the groups were assessed by the chisquared test or Fisher's exact test for categorical variables and one-way ANOVA for continuous variables. Homoskedasticity of the residuals was tested using the Goldfeld-Quandt test. Differences were considered significant at $p<0.05$. CTD signs relevant to dissection were identified using binary statistical regression: significant signs were selected stepwise from the entire set of all features by applying the Wald test method. Considering the significance of differences in CTD signs between the affected patients and the controls (the chi-squared test), additional signs were introduced in order to improve the quality of our model. This algorithm allowed us to identify CTD signs also typical of ICA and VA dissection. The model demonstrated its best predictive performance with 4 main and 2 additional signs; such combination of clinical signs was considered diagnostically relevant to ICA and VA dissection.

\section{RESULTS}

\section{Morphological changes in brain-supplying arteries}

On the macroscopic examination, dissected arteries appeared dilated and thickened, looking similar to thrombosed blood vessels. The histopathologic examination of extra- and intracranial arteries revealed changes in the internal elastic membrane: thinning, splitting, lack of physiological tortuosity, and calcifications. Some arterial segments were totally devoid of the internal elastic membrane. Changes in the tunica media were represented by its uneven thickness with areas of severe thinning, a decrease in the number of myocytes, their incorrect orientation, necrosis, areas of fibrosis and sclerosis, a decrease in the number of elastic fibers. These pathologic changes were found in both dissected and non-dissected ICA and VA (see the Figure).

\section{Clinical signs of connective tissue dysplasia and its biomarkers in patients with CeAD}

Clinical signs of CTD were more pronounced in the patients with CeAD (the average total score was $7.9 \pm 3.6$ points) than in the controls $(6 \pm 2.5 ; p=0.0039)$. Besides, they were more pronounced in females $(8.73 \pm 3.0)$ than in males $(6.4 \pm 2.5$; $p=0.05)$. The following 8 clinical signs were observed more frequently in CeAD patients than in the controls: arterial hypotension ( $51 \%$ vs $20 \%$; $p<0.012$ ), extensive bruising (40\% vs $10 \% ; p=0.011)$; widened atrophic scars on skin $(22.5 \%$ vs $0 \% ; p=0.019)$; translucent skin $(28.75 \%$ vs $5 \% ; p=0.034)$; high-arched palate (20\% vs $0 \% ; p=0.034)$; propensity to constipation (30\% vs 10\%; $p=0.05)$; nasal bleeding (33.75\% vs $15 \% ; p=0.043)$; blue sclera ( $20 \%$ vs $5 \% ; p=0.05)$. In 
addition, CeAD patients suffered from headache in the past history more often than the controls (60\% vs $35 \% ; p=0.02)$. Based on statistical significance, 8 CTD signs listed above and past history headache were divided into main (hypotension, extensive bruising, widened atrophic scars on skin, past history headache) and additional (translucent skin, nasal bleeding, propensity to constipation, blue sclera, high-arched palate) features.

According to the regression model, the maximum predictive ability for arterial dissection (77\%) was observed in the presence of 4 main and 2 additional clinical signs of CTD. In the presence of 4 main signs only, the predictive accuracy of the model was $75 \%$.

\section{Biological markers of connective tissue damage}

Patients with CeAD had elevated MMP-9 $(384 \pm 69.3 \mathrm{ng} / \mathrm{ml}$ vs $203.1 \pm 60.5 \mathrm{ng} / \mathrm{ml}$ in the controls; $p<0.0005)$, TIMP-1 $(393.9 \pm 63.4 \mathrm{ng} / \mathrm{ml}$ vs $134.4 \pm 30.8 \mathrm{ng} / \mathrm{ml}$ in the controls; $p<0.0005)$, sulphated glycosaminoglycans $(6.2 \pm 1.4 \mu \mathrm{g} / \mathrm{ml}$ vs $4.5 \pm 0.8 \mu \mathrm{g} / \mathrm{ml}$ in the controls; $p<0.0005)$, and orosomucoid $(121.6 \pm 27.8 \mathrm{mg} / \mathrm{dl}$ vs $88.8 \pm 17.4 \mathrm{mg} / \mathrm{dl}$ in the controls; $p<0.0005)$. Hydroxyproline levels were decreased in CeAD patients $(604.9 \pm 350.9 \mathrm{ng} / \mathrm{ml}$ vs $1293.6 \pm 214.5 \mathrm{ng} / \mathrm{ml}$ in the controls; $p<0.0005$ ) (Table 1). MMP-9 was higher in the patients with multiple dissections $(400.5 \pm 71.5 \mathrm{ng} / \mathrm{ml})$ than in those with one dissected ICA $(375.5 \pm 71.55 \mathrm{ng} / \mathrm{ml} ; p<0.03)$ or one dissected VA $(369.3 \pm 68.6 \mathrm{ng} / \mathrm{ml} ; p<0.08)$. TIMP-1 was also higher in the patients with multiple dissections (422.2 $\pm 53.8 \mathrm{ng} / \mathrm{ml}$ ) than in those who had only one dissected ICA $(378.5 \pm 62.3 \mathrm{ng} / \mathrm{ml} ; p<0.024)$ or one dissected VA (373.6 \pm $60.6 \mathrm{ng} / \mathrm{ml} ; p<0.008)$. In the patients with multiple dissections, sulphated glycosaminoglycans were as high as $6.8 \pm 1.2 \mu \mathrm{g} / \mathrm{ml}$, while in the patients with one dissected ICA or one dissected VA their concentrations were lower $(5.8 \pm 1.3 \mu \mathrm{g} / \mathrm{ml}$ and $5.7 \pm$ $1.5 \mu \mathrm{g} / \mathrm{ml}, p<0.029$ and $<0.016$, respectively). Orosomucoid levels were higher in the patients with multiple dissections $(129.7 \pm 34 \mathrm{mg} / \mathrm{dl})$ than in those with one dissected artery: ICA $(118.6 \pm 25.3 ; p<0.039)$ or VA $(112.6 \pm 20.6 \mathrm{mg} / \mathrm{dl}$; $p<0.011$ ) (Table 2). In the first 3 months of CeAD, orosomucoid and hydroxyproline levels were higher than in the late stage of the disease. By contrast, TIMP-1concentrations were higher in later stages. FGF-21, which is the biomarker of mitochondrial pathology [12], was increased in CeAD patients (536 $\pm 250 \mathrm{pg} / \mathrm{ml})$, as compared to the controls (204 $\pm 50 \mathrm{pg} / \mathrm{ml} ; p<0.0005)$.

\section{Factors provoking arterial dissection}

The most common provoking factors for CeAD responsible for $42 \%$ of the studied cases were neck movements and physical exertion; they were observed more often in VA dissection (61\%) than in ICA dissection (27\%; $p<0.0009)$. A minor preceding head trauma was observed in $10 \%$ of the patients (ICA - 14\%, VA - 5\%; $p<0.05$ ). Acute respiratory infection in the month preceding CeAD was reported by $14 \%$ of the patients. Twelve percent of women were on contraceptive pills before dissection.

No significant differences were observed in the incidence of dissections between the months of the year. The frequency of dissection occurrence was 9.6\%, 9.3\%, 8.1\%, 4.2\%, 8\%, $9.6 \%, 5.9 \%, 10 \%, 9.6 \%, 8.5 \%, 7.0 \%, 10.4 \%$ for January through December, respectively. No associations were found with acute respiratory infection occurring in the month preceding CeAD.

\section{Recurrences}

Twelve percent of our patients developed a recurrent dissection usually involving the opposite eponymous artery. All recurrences were verified by neuroimaging. In most cases, they occurred in the first 35 days of dissection (7.3\%), in the months that followed (within a year), their frequency was 1.5\%. Further relapses developed $3.3 \%$ of the patients 5 to 10 years later.

\section{DISCUSSION}

Clinical, laboratory and morphological examinations of CeAD patients revealed the presence of connective tissue pathology; these findings were consistent with the literature reports
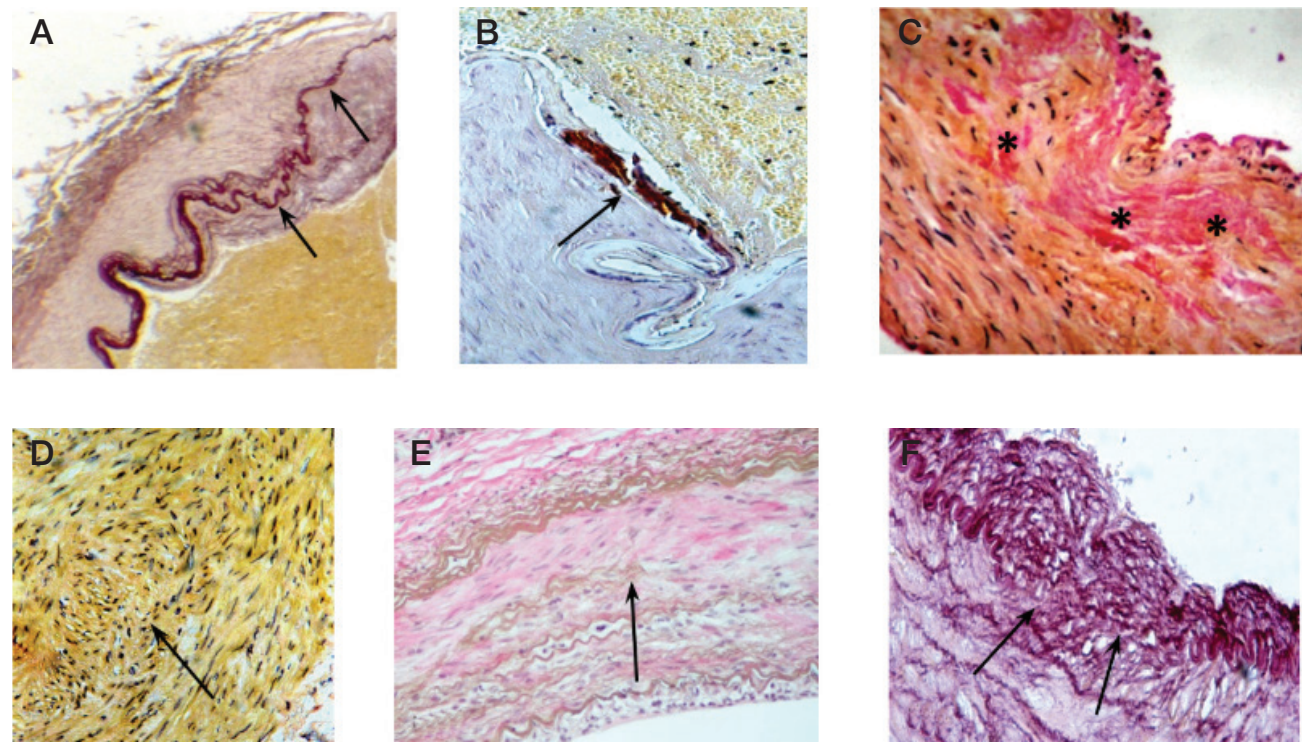

Figure. Arterial wall dysplasia in the internal carotid and vertebral arteries. A. Thinning and splitting of the internal elastic membrane in the dissected ICA siphon (shown by arrows). Staining: Weigert's elastic stain (fuchselin); x100 magnification. B. Calcium deposits on the internal elastic membrane in the dissected ICA siphon (shown by an arrow). Staining: von Kossa method; x200 magnification. C. Areas of fibrosis (marked by an asterisk) in the tunica media of the extracranial segment of the dissected ICA. Staining: van Gieson's stain; x200 magnification. D. An area of the tunica media in the dissected ICA siphon containing irregularly oriented myocyts (marked by an arrow). Staining: van Gieson's stain; x200 magnification. E. Areas of fibrosis and the decreased number of elastic fibers in the tunica media of the intact internal carotid artery (shown by an arrow). Staining: van Gieson's stain; x200 magnification. F. A fragment of the internal elastic membrane is missing (shown by an arrow) in the intact vertebral artery. Staining: Weigert's elastic stain (fuchselin); x200 magnification 
$[8,9]$. The detected abnormalities were not characteristic of well-known inherited connective tissue disorders, such as Ehlers-Danlos, Marfan or joint hypermobility syndromes, and, in our opinion, could be classified as undifferentiated. The morphological examination of both dissected and nondissected brain-supplying arteries revealed pronounced dysplastic changes, which underlay arterial wall weakness and predisposed it to dissection [13-16]. In our opinion, the changes found on microscopic examination of brain-suppling arteries are similar to those in fibromuscular dysplasia (FMD) $[13,16]$. Of note, FMD, whose international diagnostic criteria were published in 2019 [17], bears many similarities to CeAD dissection. FMD patients often develop dissections of various arteries, including ICANA, have cerebral aneurysms and tortuosity of the arteries [17], which are also typically seen in CeAD patients [18]. Many FMD patients [17], as well as CeAD patients [18], suffer from headaches. The incidence of hereditary burden in FMD (1.9-7.3\%) [17] and CeAD (2\%) [19] is similar. A genome-wide association study of FMD patients identified a common genetic risk variant: a single nucleotide polymorphism (SNP) rs9349379-A in the PHACTR1 locus (6p24) [20] also detected in CeAD patients during a multicenter international study conducted in 1,393 individuals, including our cohort of patients [21]. The adverse effect of contraceptive pills was observed in both patients with CeAD [1, 5, 22] and FMD [17]. Despite the similarity between patients with FMD and CeAD, the latter do not have the key diagnostic angiographic feature of FMD: alternating areas of stenosis and dilation (the so-called 'string of beads'). Therefore, the presence of FMD in the absence of typical angiography findings requires further investigation. The possibility of FMD can be indirectly confirmed by a case of our patient who had 3 dissection recurrences involving both ICA and the right VA plus left kidney infarction over the course of 10 years. CT-angiography of his renal arteries revealed alternating areas of narrowing and dilation - changes typically seen in FMD; those changes were not detected in the patient's ICA and VA. According to the contemporary diagnostic criteria for FMD, if a patient has typical FMD changes in at least one artery, then dissection, tortuosity or aneurysms in other arteries should be considered as manifestations of FMD. This was the case with our patient.

The cause of arterial wall dysplasia similar to that observed in CeAD patients is not completely clear [23]. According to our hypothesis, dysplasia may be associated with mitochondrial disorders [24]. Elevated FGF-21, a biomarker of mitochondrial pathology [12], found in our CeAD patients indirectly confirms this assumption. The pathogenesis of FMD also remains unknown; some authors pinpoint the significance of elevated transforming growth factors $\beta 1$ and $\beta 2$ (TGF- $\beta 1$ and TGF- 32 ) produced by fibroblasts [25].

Clinical signs of CTD were more pronounced in CeAD patients than in the controls, which is consistent with the literature reports [9]. This indicates the widespread nature of connective tissue damage, which agrees with electron microscopy findings in skin biopsies [8, 24]. The higher incidence of CTD signs in women, as compared to men, suggests that female sex hormones play a role in the development of dysplasia. Along with clinical CTD signs, we analyzed the presence of past history headaches in CeAD patients, since our previous studies revealed that headache might be associated with arterial wall dysplasia [22]; in the literature, such headache is usually interpreted as migraine [5]. The analysis of CTD signs in young patients with stroke can help to clarify the cause of stroke in cases when neuroimaging examination is not available. Statistical analysis showed that in the presence of four main and two additional CTD signs, the probability of dissection as a cause of ischemic stroke in young adults is as high as $77 \%$ [22].

Connective tissue damage in CeAD patients was confirmed by the elevated levels of CDT biomarkers (MMP-9 and sulfated glycosaminoglycans). Increased orosomucoid levels were suggestive of inflammation in the arterial wall. Laboratory signs of inflammation are also reported by other authors, who link them to a previous infection seen as a provoking factor

Table 1. CTD biomarkers in the patients with ICANA dissections in the controls (one-way ANOVA)

\begin{tabular}{|c|c|c|c|}
\hline Biomarkers $($ mean $\pm \mathrm{SD})$ & $\begin{array}{c}\text { Arterial dissection } \\
n=82\end{array}$ & $\begin{array}{c}\text { Control } \\
n=25\end{array}$ & $p$ \\
\hline MMP-9, $\mathrm{ng} / \mathrm{ml}$ & $384 \pm 69.3$ & $203.1 \pm 60.5$ & $<0.0005$ \\
\hline TIMP-1, $\mathrm{ng} / \mathrm{ml}$ & $393.9 \pm 63.4$ & $134.4 \pm 30.8$ & $<0.0005$ \\
\hline Orosomucoid, $\mathrm{mg} / \mathrm{dl}$ & $121.6 \pm 27.8$ & $88.8 \pm 17.4$ & $<0.0005$ \\
\hline Sulphated glycosaminoglycans, $\mu \mathrm{gg} / \mathrm{ml}$ & $6.2 \pm 1.4$ & $4.5 \pm 0.8$ & $<0.0005$ \\
\hline Hydroxyproline, $\mathrm{ng} / \mathrm{ml}$ & $604.9 \pm 350.9$ & $1293.6 \pm 214.5$ & $<0.0005$ \\
\hline
\end{tabular}

Note: $p$ - statistical significance; SD — standard deviation.

Table 2. CTD biomarkers in patients with different localization of arterial dissection (one-way ANOVA and post-hoc tests + Scheffe's procedure)

\begin{tabular}{|c|c|c|c|c|}
\hline \multirow[b]{2}{*}{ Biomarker $($ mean $\pm \mathrm{SD})$} & Group 1 & Group 2 & Group 3 & \multirow[b]{2}{*}{$p$} \\
\hline & $\begin{array}{c}\text { ICA dissection } \\
n=28\end{array}$ & $\begin{array}{l}\text { VA dissection } \\
\qquad n=27\end{array}$ & $\begin{array}{l}\text { Dissection of more than } 1 \text { artery } \\
\qquad n=27\end{array}$ & \\
\hline \multirow{2}{*}{ MMP-9, ng/ml } & \multirow{2}{*}{$375.5 \pm 71.5$} & \multirow{2}{*}{$369.3 \pm 68.6$} & \multirow{2}{*}{$400.5 \pm 71.5$} & Groups 1 and 30.03 \\
\hline & & & & Groups 2 and 30.008 \\
\hline \multirow{2}{*}{ TIMP-1, ng/ml } & \multirow{2}{*}{$378.5 \pm 62.3$} & \multirow{2}{*}{$373.6 \pm 60.6$} & \multirow{2}{*}{$422.2 \pm 53.8$} & Groups 1 and 30.024 \\
\hline & & & & Groups 2 and 30.008 \\
\hline \multirow{2}{*}{ Sulphated glycosaminoglycans, $\mu \mathrm{g} / \mathrm{ml}$} & \multirow{2}{*}{$5.8 \pm 1.3$} & \multirow{2}{*}{$5.7 \pm 1.5$} & \multirow{2}{*}{$6.8 \pm 1.2$} & Groups 1 and 30.029 \\
\hline & & & & Groups 2 and 30.016 \\
\hline \multirow{2}{*}{ Orosomucoid, mg/dl } & \multirow{2}{*}{$118.6 \pm 25.3$} & \multirow{2}{*}{$112.6 \pm 20.6$} & \multirow{2}{*}{$129.7 \pm 34$} & Groups 1 and 30.039 \\
\hline & & & & Groups 2 and 30.011 \\
\hline
\end{tabular}

Note: $p$ — statistical significance; ICA — internal carotid artery; VA — vertebral artery; SD — standard deviation. 
of dissection [26]. Higher levels of orosomucoid (a marker of inflammation) during the first 3 months of CeAD are also evident of inflammatory response induced by dissection. In our study, the levels of CTD biomarkers were higher in the patients with multiple dissections than in the individuals with one dissected artery, indicating more pronounced connective tissue damage in the former that led to multiple dissections. TIMP-1, an enzyme that blocks matrix proteinases, was higher in the patients examined after 3 months into dissection than in those examined in the first 3 months, which apparently was indicative of the reparative stage.

In patients with arterial wall dysplasia, ICANA dissection can be provoked by a number of factors, including head movements, minor head injury, physical exertion, acute respiratory infection in the month preceding dissection, birth pills, elevated blood pressure, alcohol consumption immediately before dissection, weight loss pills, long and frequent plane journeys [1, 5, 22]. In our patients, neck movements and physical exertion were the most frequent provoking factors (42\%), occurring more often in the individuals with VA dissection (61\%) than in those with ICA dissection (27\%). Some researchers suggest the provoking role of manual therapy [5], which some of our patients had received immediately before dissection, as well as the role of neck injuries [6, 7]. VA is especially vulnerable at the moment of neck movement because of its fixation inside the vertebral canal. Because of low elasticity of the dysplastic arterial wall, artery stretching during neck/head movement leads to intimal tears at the sites where the artery is attached to the surrounding structures. In our patients, minor head injury preceded ICA dissection more often (14\%) than VA dissection (5\%); this finding is consistent with the reports of other researchers [5]. Head injury causes brain displacement relative to the skull, which is accompanied by tension of the intracranial ICA segment and causes an intimal tear at the level where ICA enters the scull and fixed to the bones. This is a common site of IMH formation.

Recent infection (most commonly, acute respiratory infection), which is considered to be a provoking CeAD factor, was found in $14 \%$ of our patients. In young patients with ischemic stroke unrelated to dissection recent infection is not so frequent, which confirms its provoking role in CeAD [27]. Infection is accompanied by elevated leukocyte proteolytic enzymes and increased concentrations of matrix metalloproteinases that induce protein degradation in the extracellular matrix of the arterial wall and cause endothelial damage [26, 27]. Elevated levels of MMT-9 and orosomucoid revealed in our patients confirm this mechanism of provoking action of infection.

Contraceptive pills as a factor provoking dissection was detected in $12 \%$ of female participants, which is less common than in European studies [6, 7]. The mechanism underlying the effect of contraceptives on the arterial wall is unknown; perhaps they aggravate dysplastic changes in the arterial wall, predisposing it to dissection.

Some authors point to the role of seasonal weather changes because CeAD occurs in cold periods more often. It is hypothesized that elevated arterial pulse pressure and frequent respiratory infections at the cold time of the year may provoke arterial dissection [28, 29]. In our study we did not find any significant differences in the CeAD incidence between the months of the year and did not detect any associations with infections. Atmospheric instability in general and air pressure fluctuations in particular are common to all seasons in the middle part of Russia, where the majority of our patients were residing. Perhaps, low atmospheric pressure is a pathogenically important environmental factor since it causes arteries to dilate. In this case, an intimal tear can occur at the site of more severe morphological changes (defects of the internal elastic membrane, a thin tunica media with few elastic fibers, areas of fibrosis, myocyte necrosis).

Although the mechanism of action is clear for most provoking factors, there is still no explanation as to why CeAD recurrences are rare, given that these factors are very common in everyday life (head turns, physical exercise, respiratory infections, etc.) and that, according to our morphological data, dysplasia involves all brain suppling arteries. Recurrences verified by neuroimaging occurred in $12.1 \%$ of our patients, usually in the first 35 days of CeAD (7.3\%); in the few months that followed (within a year) their frequency was 1.5\%. Further relapses developed in 3.3\% of patients within 5 to 10 years. The true recurrence rate in the first month of CeAD seems to be higher, since the first neuroimaging examination carried out in this period revealed multiple dissections in $22 \%$ of our patients. According to other authors, relapses occur more often in the first weeks of the disease, and their frequency is less than $3 \%$. The late-term recurrence rate among 200 patients observed for 7.4 years was $7 \%$ [30].

The highest recurrence rate in the first month after dissection and the low recurrence frequency in later follow-up periods allowed us to hypothesize the existence of critical periods when the arterial wall weakens and becomes susceptible to dissection. Along with infection and hormonal changes seen in a number of our patients, some endogenous metabolic disorders leading to degradation of the extracellular matrix, necrosis of myocytes in media, and impairment of fibroblast function, seem to be important [13]. From the standpoint of our concept that sees mitochondrial cytopathy as a cause of arterial wall dysplasia [24], a parallel can be drawn to an energy crisis characteristic of mitochondrial diseases, which could explain the low rate of late and the high rate of early dissection recurrences.

\section{CONCLUSIONS}

Arterial wall weakness due to its dysplasia predisposes patients to CeAD; the morphological changes in the arterial wall in CeAD are similar to those in FMD. 2. Endogenous and exogenous factors can severely aggravate dysplasia, which at a critical point can lead to spontaneous or provoked arterial dissection. 3. The critical period lasts about a month; this is when recurrences are most likely to happen. In order to prevent them, it is important to avoid abrupt head movements and wear a neck orthosis. 4. A repeated MRI scan of cervical arteries is recommended at the end of the first month to catch a possible clinically asymptomatic recurrence. 5. Further research into the pathogenesis of arterial wall dysplasia in CeAD will help to develop a pathogenetically based preventive treatment.

\section{References}

1. Kalashnikova LA, Dobrynina LA. Dissekcija arterij golovnogo mozga: ishemicheskij insul't i drugie klinicheskie projavlenija. M.:
Izd-vo «Vako», 2013; 208 s. Russian.

2. Robertson JJ, Koyfman A. Cervical artery dissection: a review. J 
Emerg Med. 2016; 51 (5): 508-18. PubMed PMID: 27634674.

3. Hakimi R, Sivakumar S. Imaging of Carotid Dissection. Curr Pain Headache Rep. 2019; 23 (1): 2. PubMed PMID: 30661121

4. Kalashnikova LA, Dobrynina LA, Dreval MV, Doronina EV Nazarova MA. Shejnaya i golovnaja bol' kak edinstvennoe projavlenie dissekcii vnutrennej sonnoj i pozvonochnoj arterij. Zhurnal nevrologii i psihiatrii im. Korsakova. 2015; (3): 9-16. PubMed PMID: 24300790. Russian.

5. Débette S. Pathophysiology and risk factors for cervical artery dissection: what have we learned from large hospital-based cohorts? Curr Opin Neurol. 2014; (1): 20-8. PubMed PMID: 24300790

6. von Babo M, De Marchis GM, Sarikaya H, Stapf C, Buffon F, Fischer $U$, et al. Differences and similarities between spontaneous dissections of the internal carotid artery and the vertebral artery. Stroke. 2013; 44 (6): 1537-42. PubMed PMID: 23632978.

7. Debette S, Grond-Ginsbach C, Bodenant M, Kloss M, Engelter S, Metso, et al. Differential features of carotid and vertebral artery dissections: the CADISP study. Neurology. 2011; 77 (12): 1174 81. PubMed PMID: 21900632

8. Brandt T, Hausser I, Orberk E, Grau A, Hartschuh W, AntonLamprecht I, et al. Ultrastructural connective tissue abnormalities in patients with spontaneous cervicocerebral artery dissections. Ann Neurol. 1998; (44): 281-285. PubMed PMID: 9708556.

9. Giossi A, Ritelli M, Costa P, Morotti A, Poli L, Del Zotto E, et al Connective tissue anomalies in patients with spontaneous cervical artery dissection. Neurology. 2014; 83 (22): 2032-7. PubMed PMID: 25355826.

10. Grond-Ginsbach C, Thomas-Feles C, Werner I, Weber R, Wigger F, Hausser I, et al. Mutations in the tropoelastin gene (ELN) were not found in patients with spontaneous cervical artery dissections. Stroke. 2000; 31 (8): 1935-8. PubMed PMID: 10926960.

11. Grond-Ginsbach C, Weber R, Haas J, Orberk E, Kunz S., Busse O, et al. Mutations in the COL5A1 coding sequence are not common in patients with spontaneous cervical artery dissections. Stroke. 1999; 30 (9):1887-90. PubMed PMID: 10471441.

12. Lehtonen JM, Forsström S, Bottani E, Viscomi C, Baris OR, Isoniemi $\mathrm{H}$, et al. FGF 21 is a biomarker for mitochondrial translation and mtDNA maintenance disorders. Neurology. 2016 87 (22): 2290-9. PubMed PMID: 27794108.

13. Kalashnikova LA, Gulevskaya TS, Anufriev PL, Gnedovskaja EV, Konovalov RN, Piradov MA. Ischemic stroke in young age due to dissection of intracranial carotid artery and its branches (clinical and morphological study). Annals of Clinical and Experimental Neurology. 2009; 3 (1): 18-24. Russian.

14. Anderson RM, Schechter MM. A case of spontaneous dissecting aneurysm of the internal carotid artery. J Neurol Neurosurg Psychiatry. 1959; (22): 195-201. PMID: 13793447.

15. Southerland AM, Meschia JF, Worrall BB. Shared associations of nonatherosclerotic, large-vessel, cerebrovascular arteriopathies: considering intracranial aneurysms, cervical artery dissection, moyamoya disease and fibromuscular dysplasia. Curr Opin Neurol. 2013; (26): 13-28. PubMed PMID: 23302803.

16. Kalashnikova LA, Chaykovskaya RP, Gulevskaya TS, Dobrynina LA, Gubanova MV, Dreval MV, et al. Intimal rupture of the displastic middle cerebral artery wall complicated by thrombosis and fata ischemic stroke. Zh Nevrol Psikhiatr Im S S Korsakova. 2018; 118 (3): 9-14. PubMed PMID: 29798974. Russian.

\section{Литература}

1. Калашникова Л. А., Добрынина Л. А. Диссекция артерий головного мозга: ишемический инсульт и другие клинические проявления. М.: Изд-во «Вако», 2013; 208 с.

2. Robertson JJ, Koyfman A. Cervical artery dissection: a review. J Emerg Med. 2016; 51 (5): 508-18. PubMed PMID: 27634674.

3. Hakimi R, Sivakumar S. Imaging of Carotid Dissection. Curr Pain Headache Rep. 2019; 23 (1): 2. PubMed PMID: 30661121.

4. Калашникова Л. А., Добрынина Л. А., Древаль М. В., Доронина Е. В., Назарова М. А. Шейная и головная боль как единственное проявление диссекции внутренней сонной и позвоночной артерий. Журнал неврологии и психиатрии им. Корсакова. 2015; (3): 9-16. PubMed PMID: 24300790.
17. Gornik HL, Persu A, Adlam D, Aparicio LS, Azizi M, Boulanger M, et al. First International Consensus on the diagnosis and management of fibromuscular dysplasia. Vascular Medicine. 2019; 24 (2): 16489. PubMed PMID: 306448921

18. De Giuli V, Grassi M, Lodigiani C, Patella R, Zedde M, Gandolfo C, et al. Association between migraine and cervical artery dissection: the Italian project on stroke in young adults. JAMA Neurol. 2017; 74 (5) 512-18. PubMed PMID: 28264095

19. Schievink WI, Mokri B, Piepgras DG, Kuiper JD. Recurrent spontaneous artery dissections. Risk in familial versus nonfamilial disease. Stroke. 1996; 27 (4): 622-4. PubMed PMID: 8614918.

20. Kiando SR, Tucker NR, Castro-Vega LJ, Katz A, D'Escamard V, Tréard C, et al. PHACTR1 is a genetic susceptibility locus for fibromuscular dysplasia supporting its complex genetic pattern of inheritance. PLOS Genet. 2016; 12 (10): e1006367. PubMed PMID: 27792790

21. Debette S, Kamatani Y, Metso TM, Kloss M, Chauhan G, Engelter ST, et al. Common variation in PHACTR1 is associated with susceptibility to cervical artery dissection. Nat Genet. 2015; 47 (1): 78-83. PubMed PMID: 25420145.

22. Gubanova MV, Kalashnikova LA, Dobrynina LA, Shamtieva KV, Berdalin AB. Markery displazii soedinitel'noj tkani pri dissekcii magistral'nyh arterij golovy i provocirujushhie faktory dissekcii. Annaly klinicheskoj i jeksperimental'noj nevrologii. 2017; 11 (4): 19-28. DOI: 10.18454/ACEN.2017.4.2. Russian.

23. Hausser I, Muller U, Engelter S, Lyrer P, Pezzini A, Padovani A, et al. Different types of connective tissue alterations associated with cervical artery dissections. Acta Neuropathol. 2004; 107 (6): 509-14. PubMed PMID: 15067552.

24. Sakharova AV, Kalashnikova LA, Dobrynina LA, Chaykovskaya RP, Mir-Kasimov MF, Nazarova MA, et al. Morphological signs of mitochondrial cytopathy in skeletal muscles and micro-vessels in a patient with cerebral artery dissection associated with MELAS syndrome. Arkhiv patologii. 2010; 74 (2): 51-6. Russian.

25. Ganesh SK, Morissette R, Xu Z, Schoenhoff F, Griswold BF, Yang J, et al. Clinical and biochemical profiles suggest fibromuscular dysplasia is a systemic disease with altered TGF- $\beta$ expression and connective tissue features. FASEB J. 2014; 28 (8): 3313-24. PubMed PMID: 24732132.

26. Grond-Ginsbach C, Giossi A, Aksay SS, Engelter ST, Lyrer PA, Metso TM, et al. Elevated peripheral leukocyte counts in acute cervical artery dissection. Eur J Neurol. 2013; 20 (10):1405-10. PubMed PMID: 23879551.

27. Guillon B, Berthet K, Benslamia L, Bertrand M, Bousser MG, Tzourio C. Infection and the risk of spontaneous cervical artery dissection: a case-control study. Stroke. 2003; 34 (7): 79-81. PubMed PMID: 12805497

28. Schievink WI, Wijdicks EF, Kuiper JD. Seasonal pattern of spontaneous cervical artery dissection. J Neurosurg. 1998; 89 (1): 101-3. PubMed PMID: 9647179.

29. Kloss M, Metso A, Pezzini A, Leys D, Giroud M, Metso TM, et al. Towards understanding seasonal variability in cervical artery dissection (CeAD). J Neurol. 2012; 259 (8):1662-7. PubMed PMID: 22286657

30. Schievink WI, Mokri B, O'Fallon WM. Recurrent spontaneous cervical-artery dissection. N Engl J Med. 1994; 330 (6): 393-7. PubMed PMID: 8284004.

5. Débette S. Pathophysiology and risk factors for cervical artery dissection: what have we learned from large hospital-based cohorts? Curr Opin Neurol 2014; (1): 20-8. PubMed PMID: 24300790.

6. von Babo M, De Marchis GM, Sarikaya H, Stapf C, Buffon F, Fischer $U$, et al. Differences and similarities between spontaneous dissections of the internal carotid artery and the vertebral artery. Stroke. 2013; 44 (6): 1537-42. PubMed PMID: 23632978.

7. Debette S, Grond-Ginsbach C, Bodenant M, Kloss M, Engelter S, Metso, et al. Differential features of carotid and vertebral artery dissections: the CADISP study. Neurology. 2011; 77 (12): 117481. PubMed PMID: 21900632. 
8. Brandt T, Hausser I, Orberk E, Grau A, Hartschuh W, AntonLamprecht I, et al. Ultrastructural connective tissue abnormalities in patients with spontaneous cervicocerebral artery dissections. Ann Neurol. 1998; (44): 281-285. PubMed PMID: 9708556.

9. Giossi A, Ritelli M, Costa P, Morotti A, Poli L, Del Zotto E, et al. Connective tissue anomalies in patients with spontaneous cervical artery dissection. Neurology. 2014; 83 (22): 2032-7. PubMed PMID: 25355826.

10. Grond-Ginsbach C, Thomas-Feles C, Werner I, Weber R, Wigger F, Hausser I, et al. Mutations in the tropoelastin gene (ELN) were not found in patients with spontaneous cervical artery dissections. Stroke. 2000; 31 (8): 1935-8. PubMed PMID: 10926960.

11. Grond-Ginsbach C, Weber R, Haas J, Orberk E, Kunz S., Busse O, et al. Mutations in the COL5A1 coding sequence are not common in patients with spontaneous cervical artery dissections. Stroke. 1999; 30 (9):1887-90. PubMed PMID: 10471441

12. Lehtonen JM, Forsström S, Bottani E, Viscomi C, Baris OR, Isoniemi $\mathrm{H}$, et al. FGF 21 is a biomarker for mitochondrial translation and mtDNA maintenance disorders. Neurology. 2016; 87 (22): 2290-9. PubMed PMID: 27794108.

13. Калашникова Л. А., Гулевская Т. С., Ануфриев П. Л., Гнедовская Е. В., Коновалов Р. Н., Пирадов М. А. Ишемический инсульт в молодом возрасте, обусловленный стенозирующим расслоением (диссекцией) интракраниального отдела внутренней сонной артерии и ее ветвей (клиникоморфологическое наблюдение). Анналы клинической и экспериментальной неврологии. 2009; 3 (1): 18-24.

14. Anderson RM, Schechter MM. A case of spontaneous dissecting aneurysm of the internal carotid artery. J Neurol Neurosurg Psychiatry. 1959; (22): 195-201. PMID: 13793447.

15. Southerland AM, Meschia JF, Worrall BB. Shared associations of nonatherosclerotic, large-vessel, cerebrovascular arteriopathies: considering intracranial aneurysms, cervical artery dissection, moyamoya disease and fibromuscular dysplasia. Curr Opin Neurol. 2013; (26): 13-28. PubMed PMID: 23302803.

16. Калашникова Л. А., Чайковская Р. П., Гулевская Т. С., Добрынина Л. А., Губанова М. В., Древаль М. В., Максимова М. Ю. Разрыв интимы при дисплазии стенки средней мозговой артерии, осложнившийся тромбозом и развитием тяжелого ишемического инсульта (клинико-морфологическое наблюдение). Журнал неврологии и психиатрии им. С. С. Корсакова. 2018; 118 (3): 9-14. PubMed PMID: 29798974.

17. Gornik HL, Persu A, Adlam D, Aparicio LS, Azizi M, Boulanger M, et al. First International Consensus on the diagnosis and management of fibromuscular dysplasia. Vascular Medicine. 2019; 24 (2): 16489. PubMed PMID: 306448921

18. De Giuli V, Grassi M, Lodigiani C, Patella R, Zedde M, Gandolfo C, et al. Association between migraine and cervical artery dissection: the Italian project on stroke in young adults. JAMA Neurol. 2017; 74 (5) 512-18. PubMed PMID: 28264095.

19. Schievink WI, Mokri B, Piepgras DG, Kuiper JD. Recurrent spontaneous artery dissections. Risk in familial versus nonfamilial disease. Stroke. 1996; 27 (4): 622-4. PubMed PMID: 8614918.

20. Kiando SR, Tucker NR, Castro-Vega LJ, Katz A, D'Escamard V, Tréard C, et al. PHACTR1 is a genetic susceptibility locus for fibromuscular dysplasia supporting its complex genetic pattern of inheritance. PLOS Genet. 2016; 12 (10): e1006367. PubMed PMID: 27792790

21. Debette S, Kamatani Y, Metso TM, Kloss M, Chauhan G, Engelter ST, et al. Common variation in PHACTR1 is associated with susceptibility to cervical artery dissection. Nat Genet. 2015; 47 (1): 78-83. PubMed PMID: 25420145.

22. Губанова М. В., Калашникова Л. А., Добрынина Л. А., Шамтиева К. В., Бердалин А. Б. Маркеры дисплазии соединительной ткани при диссекции магистральных артерий головы и провоцирующие фракторы диссекции. Анналь клинической и экспериментальной неврологии. 2017; 11 (4): 19-28. DOI: 10.18454/ACEN.2017.4.2.

23. Hausser I, Muller U, Engelter S, Lyrer P, Pezzini A, Padovani A, et al. Different types of connective tissue alterations associated with cervical artery dissections. Acta Neuropathol. 2004; 107 (6): 509-14. PubMed PMID: 15067552.

24. Сахарова А. В., Калашникова Л. А., Чайковская Р. П., Добрынина Л. А., Мир-Касимов М. Ф. Назарова М. А. и др. Морфологические и ультраструктурные признаки митохондриальной цитопатии в скелетных мышцах и микрососудах мышц и кожи при диссекции церебральных артерий, ассоциированной с мутацией A3243G в митохондриальной ДНК. Архив патологии. 2012; 74 (2): 51-6.

25. Ganesh SK, Morissette R, Xu Z, Schoenhoff F, Griswold BF, Yang J, et al. Clinical and biochemical profiles suggest fibromuscular dysplasia is a systemic disease with altered TGF- $\beta$ expression and connective tissue features. FASEB J. 2014; 28 (8): 3313-24. PubMed PMID: 24732132

26. Grond-Ginsbach C, Giossi A, Aksay SS, Engelter ST, Lyrer PA, Metso TM, et al. Elevated peripheral leukocyte counts in acute cervical artery dissection. Eur J Neurol. 2013; 20 (10):1405-10. PubMed PMID: 23879551.

27. Guillon B, Berthet K, Benslamia L, Bertrand M, Bousser MG, Tzourio C. Infection and the risk of spontaneous cervical artery dissection: a case-control study. Stroke. 2003; 34 (7): 79-81. PubMed PMID: 12805497.

28. Schievink WI, Wijdicks EF, Kuiper JD. Seasonal pattern of spontaneous cervical artery dissection. J Neurosurg. 1998; 89 (1): 101-3. PubMed PMID: 9647179

29. Kloss M, Metso A, Pezzini A, Leys D, Giroud M, Metso TM, et al. Towards understanding seasonal variability in cervical artery dissection (CeAD). J Neurol. 2012; 259 (8):1662-7. PubMed PMID: 22286657

30. Schievink WI, Mokri B, O'Fallon WM. Recurrent spontaneous cervical-artery dissection. N Engl J Med. 1994; 330 (6): 393-7. PubMed PMID: 8284004 